Кубишина Н.C. канд. економ. наук, доиент ORCID ID: 0000-0002-0563-1421

Стасевич А.П. ORCID ID: 0000-0002-5897-4225 Національний технічний університет Украйни «Київський політехнічний інститут імені Ігоря Сікорського»

\title{
РОЗРОБЛЕННЯ МОДЕЛІ ВИВЕДЕННЯ НОВОГО ТОВАРУ ТМ «МОЛОКІЯ КАЗКОВА» НА СПОЖИВЧИЙ РИНОК
}

\section{РАЗРАБОТКА МОДЕЛИ ВЫВОДА НОВОГО ТОВАРА ТМ «МОЛОКИЯ СКАЗОЧНАЯ» НА ПОТРЕБИТЕЛЬСКИЙ РЫНОК}

\section{DEVELOPMENT OF A MODEL OF NEW PRODUCT TM "MILK KASKOVA" TO THE CONSUMER MARKET}

У статті проаналізовано поняття «новий товар» та етапи виведення нового товару на ринок. Запропоновано модель виведення нового товару на споживчий ринок на прикладі ПрАТ «Тернопільський молокозавод», щзо на відміну від існуючих відрізняється наступними етапами: аналіз мікро- та макросередовища підприємства, методи формування товарного асортименту, конщепція нового товару, виведення нового товару, товарна стратегія, ринкова стратегія нового товару. На основі даної моделі розроблено комплекс маркетингу та ринкову стратегію для нового товару, а саме дитячого йогурту 2,7 \% жирності ТМ «Молокія Казкова». Для товарного асортименту ТМ «Молокія Казкова» згідно результатів дослідження доиільно обрати стратегію «розширення асортименту». Найкращими варіантами щодо випуску нової продукції являються регіони: Тернопільська, Волинська та Рівненська області. Для інформування потенційних споживачів про нову продукиію ТМ «Молокія Казкова», а саме дитячий йогурт пропонується використовувати: рекламу, стимулювання збуту та $P R$.

Ключові слова: новий товар, модель, матриця Бостинської консалтингової групи, споживчий ринок, ринкова стратегія, комплекс маркетингу.

В статье проанализированы понятия «новый товар» и этапы вывода нового товара на рынок. Предложена модель вывода нового товара на потребительский рынок на примере 3 АО «Тернопольский молокозавод», что в отличие от существующих отличается следующими этапами: анализ микро- и макросреды предприятия, методы формирования товарного ассортимента, концепция нового товара, вывод нового товара, товарная стратегия, рыночная стратегия нового товара. На основе данной модели разработан комплекс маркетинга и рыночную стратегию для нового товара, а именно детского йогурта 2,7\% жирности ТМ «Молокия Сказочная». Для товарного ассортимента ТМ «Молокия Сказочная» согласно результатам исследования иелесообразно выбрать стратегию «расширения ассортимента». Лучшими вариантами по выпуску новой продукции являются регионы Тернопольская, Волынская и Ровенская области. Для информирования потенииальных потребителей о новой продукиии ТМ «Молокия Сказочная», а именно детский йогурт предлагается использовать: рекламу, стимулирование сбыта и $P R$.

Ключевые слова: новый товар, модель, матрица Бостонской консалтинговой группы, потребительский рынок, рыночная стратегия, комплекс маркетинга. 
The article analyses the concept of "new product" and the stages of the output of a new product on the market. The model output of a new product to the consumer market by the example of PJSC "Ternopil dairy factory", unlike the existing different following steps: analysis of micro and macro enterprise, methods of forming product lines, the concept of a new product, new product output, product strategy, market strategy new product based on the model developed marketing mix and marketing strategy for a new product, namely baby fat yogurt 2.7\% TM "Molokiya Fairy." For product range TM "Fairy Molokiya" according to the survey results it is advisable to choose the strategy of "expanding the range." The best options for the production of new products are the regions: Ternopil, Volyn and Rivne regions. To inform potential customers about new products TM "Molokiya Fairy", namely children's yogurt proposed use: advertising, sales promotion and PR.

Keywords: new product, model, Boston Consulting Group Matrix, consumer market, market strategy, marketing mix.

Вступ. В умовах жорсткої конкуренції підприємствам необхідно орієнтуватись на задоволення потреб споживачів, забезпечуючи при цьому економічну ефективність. Важливе значення набуває проблема посилення конкурентоспроможності та їхньої продукції.Зважаючи на те, що ринок молочної продукції насичений, саме процесу розроблення та виведення новинок приділяється значна увага. Від цього буде залежати комерційний успіх підприємства.

Дослідженням питання розроблення та виведення нових товарів займались вітчизняні та зарубіжні науковці, серед нихН. Моісеєва, В. Кардаш, А. Войчак, Н. Кубишина, А. Павленко, Ж. Ламбен, Р.Купера, П.Савіотті, Т. Амблер, Є. Голубков. У своїх працях вчені розглядають здебільшого планування та розробку нового товару, але не в повній мірі розкритимзалишається питання безпосередньо моделі виведення нового товару на споживчий ринок.

Постановка завдання. Метою статті $\epsilon$ розроблення моделі виведення нового товару на споживчий ринок на прикладі виробничого підприємства ПрАТ «Тернопільський молокозавод».

Методологія. Теоретико-методологічною та інформаційною базою дослідження базою стали загальнонаукові, матричні аналітичні методита спеціальні методи економіко-математичного аналізу, матеріали періодичних видань, праці вітчизняних та зарубіжних науковців,дані Державного комітету статистики України статистичні дані вітчизняних підприємств, що представлені на споживчому ринку України.

Результати дослідження. В умовах кризи сучасному підприємству, для того, щоб залишатися успішним необхідно постійно розвиватися та удосконалювати свою продукцію.Запорукою конкурентоспроможності підприємства $є$ створення нових товарів, що будуть задовольняти потреби споживачів, що дозволить збільшити частку ринку та відповідно максимізувати прибуток підприємства.

Новий товар - це товар, щонадійшов на ринок і відрізняється від існуючих аналогів зміною споживчих та/або технічних властивостей.[4] 
За певними оцінками тільки 10\% товарів, що з'являються на ринку, можуть бути віднесені до так званих світових новинок, 20\% - товари, нові для фірми; 26\% розширення наявної гами продуктів, $26 \%$ оновлені продукти, $7 \%$ - зміна позиціонування продукту та 11\% - це виробнича інновація[9].

Процес розроблення нового товару передбачає вісім послідовних етапів: генерування ідей; відбір ідей; розробка замислу; розробка стратегії маркетингу; економічний аналіз; розробка товару-прототипу; пробний маркетинг та розвертання комерційного виробництва.

За даними досліджень у середньому близько 35 \% нових товарів зазнають невдачі на ринку, тому перед прийняттям рішення про виведення нового товару на ринок, необхідно проводити маркетингове дослідження.

Розроблення моделі виведення нового товару на ринок передбачало проведення маркетингового дослідження та аналізу товарного асортименту за допомогою матриці Бостинської консалтингової групи.

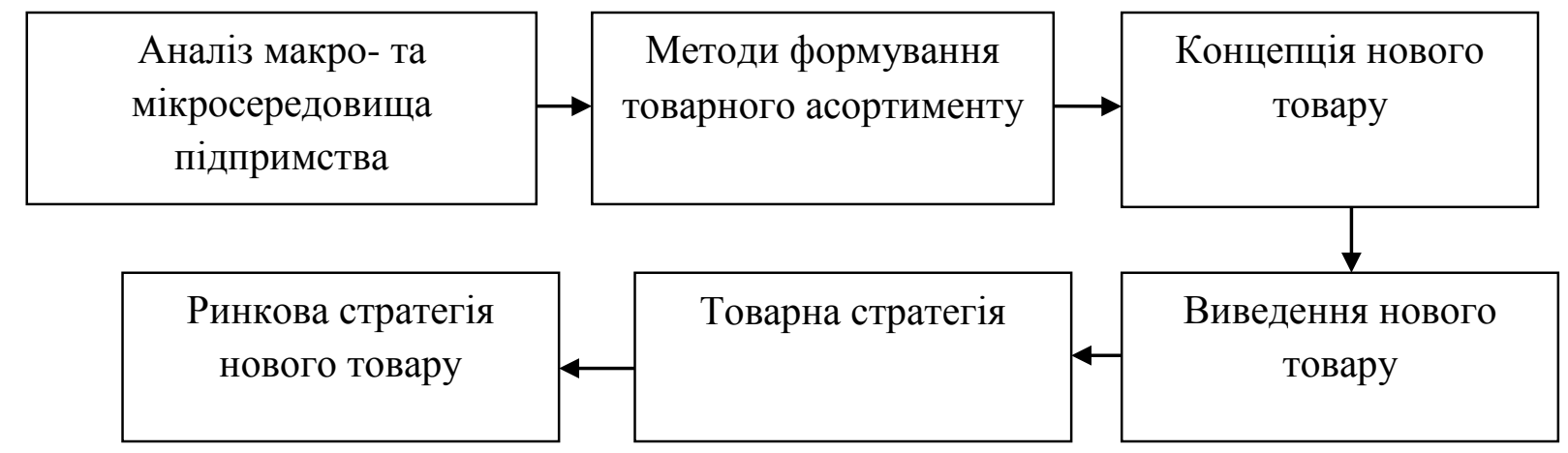

Рис. 1. Модель виведення нового товару на споживчий ринок [Авторська розробка]

1. Аналіз макро- та мікросередовища підприємства. Згідно результатів аналізу підприємство має розвинену інфраструктуру, що дозволяє вивести на ринок новий товар. Зробивши аналіз ринку молочної продукції підприємства, можна зробити висновок, що перспективним новим товаром для виведення $\epsilon$ дитячий йогурт для дітей від 8 місяців.

2. Методи формування товарного асортименту. Аналіз товарного асортименту ТМ «Молокія Казкова» було проведено задопомогою методики на основі матриці Бостинської консалтингової групи. Згідно матриці БКГ, молоко ТМ «Молокія Казкова» знаходиться у секторі «зірки»; йогурт - сектор «дійні корови» та у секторі «собаки» знаходиться масло ТМ «Молокія Казкова». Для кожної із даних категорій товару запропоновано стратегії, що дозволить максимізувати прибуток підприємства та збільшити частку ринку. Для категорії товару молоко необхідно використовувати стратегію, що використовують для «зірок», а саме утримання даних позицій та збільшення і оптимізація наявної частки ринку. Для йогурту, що знаходиться у секторі «дійні корови» необхідно 
використовувати стратегію «збереження наявної частки ринку». Дана категорія товару не потребує значних інвестицій, але при цьому надає стабільний прибуток підприємству. Кошти, що приносить «йогурт» можна направити на новий товар, що тільки виходить на ринок. Для масла ТМ «Молокія Казкова необхідно збільшити частку ринку та застосувати стратегію «збирання врожаю», тобто отримання короткострокового прибутку в максимально можливих розмірах. На основі запропонованих стратегій для портфелю товарів ТМ «Молокія Казкова», побудовано адаптовану матрицю БКГ (рис. 2).

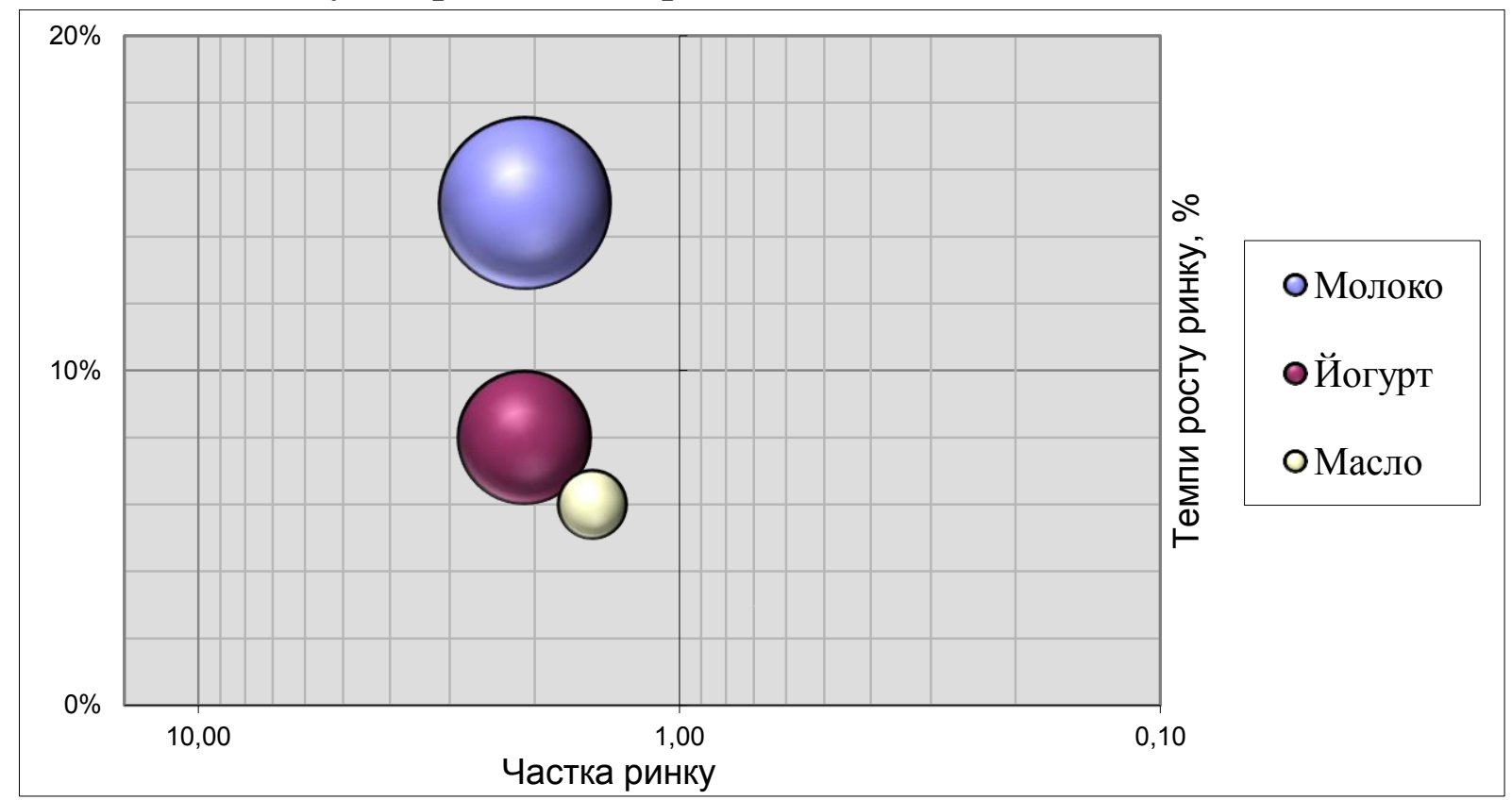

Рис. 2. Адаптована матриця Бостинської консалтингової групи ТМ «Молокія Казкова»

Зірки займають відносно велику частку бурхливо зростаючого ринку, операції на якому приносять високі прибутки. Ці товари можна назвати лідерами своїх галузей, що приносять організаціям дуже високий дохід. У секторі «зірки» знаходиться молоко ТМ «Молокія Казкова, яка приносить найбільший прибуток та має найбільший показник темпу росту ринку.

Дійні корови - це товари, які торік отримали відносно велику частку ринку, проте з часом зростання відповідних товарів помітно сповільнився. Дійні корови забезпечують достатній прибуток для того, щоб утримати на ринку свої конкурентні позиції. В секторі «дійні корови» знаходяться йогурти та масло ТМ «Молокія Казкова». Дані товари, зокрема йогурт потребує інвестиційний мінімум, та при цьому може принести великі прибутки.

3. Кониепиія нового товару розглядається завдяки трьох рівнів товару. Як товар, за задумом дитячий йогурт для дітей від 8 місяців ТМ «МолокіяКазкова» $\epsilon$ 
натуральним молочним продуктом дитячого харчування для збалансованого щоденного раціону дитини. До вигод від використання дитячого йогурту можна віднести (діти та батьки дітей): вгамування голоду (смачний напій у зручній упаковці);стимулювання і активізація травлення дитини; нормалізація балансу корисних бактерій в шлунку і кишечнику дитини; стимулювання i активізація травлення; насичення організму біфідобактеріями, білками, лактобактеріями, лактозою та пробіотиками, кальцій; перешкода розвитку кишкових захворювань та інфекцій; збалансування щоденного раціону дитини.

Новий дитячий йогурт 2,7\% жирності випускатиметься під ТМ «Молокія Казкова», дана марочна назва $є$ маркою ПрАТ «Тернопільський молокозавод». Назва була обрана ще у 2005 році та означає: «молоко» - безпосередньо, що виробляє торгова марка; «і я» - акцентує увагу на тому, що виробник піклується про кожного споживача продукції підприємства; «казкова» - асоціації 3 дитинством. У графічному зображенні використовується досить багато яскравих кольорів, але переважають: жовтий, червоний, білий, оранжевий та голубим. Така яскрава кольорова гама асоціюється з дитинством.

Якість продукції «Молокія Казкова» підтверджена стандартами ДСТУ, ISO 9001:2009 за міжнародною системою керування якістю. До основних властивостей дитячого йогурту можна віднести: покращує роботу шлунку, добре насичує і втамовує спрагу; допомагає відновити і зберегти здоров'я кишечника: активізує ріст корисних мікроорганізмів, очищає кишечник від шлаків, покращує травлення, сприяє кращому засвоєнню їжі; підвищує імунітет.

Упаковкою дитячого йогурту 2,7\% жирності буде пляшка з HDPE об'ємом 200 г. та контейнер з HDPE об’ємом 100г.. Даний матеріал та об’єм забезпечує зручність у використанні.

Третій рівень товару, а сааме дитячого йогурту буде забезпечуватись центром співпраці зі споживачами ПрАТ «Тернопільський молокозавод». 3 усіми скаргами та пропозиціями споживачі можуть цілодобово та безкоштовно звернутися за телефоном та на електрону пошту.

4. Виведення нового товару потребує розроблення комплексу маркетингу для товару. У стратегії ціноутворення у відношенні «якість-ціна» підприємство ПрАТ «Тернопільський молокозавод» для ТМ «Молокія Казкова» дитячий йогурт, доцільно обрати стратегію «глибокого проникнення на ринок» таблиця . 
Таблиия 1

Матриця цінових стратегій в залежності від співвідношення «ціна-якість»

\begin{tabular}{|c|c|c|c|}
\hline \multirow{2}{*}{$\begin{array}{l}\text { Якість } \\
\text { товару }\end{array}$} & Висока & Середня & Низька \\
\hline висока & $\begin{array}{c}\text { Стратегія преміальних } \\
\text { націнок }\end{array}$ & $\begin{array}{c}\text { Стратегія глибокого } \\
\text { проникнення на ринок }\end{array}$ & $\begin{array}{c}\text { Стратегія підвищеної } \\
\text { ціннісної значимості }\end{array}$ \\
\hline середня & Стратегія завищеної ціни & $\begin{array}{c}\text { Стратегія середнього } \\
\text { рівня цін }\end{array}$ & $\begin{array}{c}\text { Стратегія } \\
\text { доброякісності }\end{array}$ \\
\hline низька & Стратегія пограбування & $\begin{array}{c}\text { Стратегія показного } \\
\text { блиску }\end{array}$ & $\begin{array}{c}\text { Стратегія низької } \\
\text { ціннісної значимості }\end{array}$ \\
\hline
\end{tabular}

Стратегія глибокого проникнення характеризується пропозицією товарів високої якості за середньою ціною. Якість продукції ТМ «Молокія Казкова» підтверджена стандартами ISO та застосуванням європейської технології FreshMilk. Дитячий йогурт $2,7 \%$ жирності буде виготовлений згідно усіх стандартів якост, застосовуючи технологію FreshMilk та використовуючи «живі» закваски для йогурту.

Таблиия 2

Ціни на дитячий йогурт 2,7\% жирності ТМ «Молокія Казкова»

\begin{tabular}{|c|c|}
\hline Продукція & Ціна, грн. \\
\hline Йогурт дитячий 2,7\% пляшка з HDPE 200 г. (без наповнювача) & 10,85 \\
\hline Йогурт дитячий 2,7\% пляшка з HDPE 200 г. (яблуко-груша) & 11,00 \\
\hline Йогурт дитячий 2,7\% пляшка з HDPE 200 г. (чорниця-малина) & 11,00 \\
\hline $\begin{array}{l}\text { Йогурт дитячий } \\
\text { наповнювача) }\end{array}$ & 8,45 \\
\hline Йогурт дитячий 2,7\% контейнер HDPE 100 г. (яблуко-груша) & 8,55 \\
\hline Йогурт дитячий 2,7\% контейнер HDPE 100 г. (чорниця-малина) & 8,55 \\
\hline
\end{tabular}

Для того, щоб обрати ринки збуту для нової продукції було проведено дослідження за допомогою матриці Бостинської консалтингової групи дванадцяти областей реалізації продукції ТМ «Молокія Казкова». Згідно отриманих результатів, можна зробити висновок, що мають найбільшу частку ринку та відповідно являються найкращими варіантами щодо випуску нової продукції три регіони, а саме Тернопільська, Волинська та Рівненська області. Дитячий йогурт, 2,7\% жирності ТМ «Молокія Казкова» буде реалізуватись у роздрібних мережах Тернопільської, Рівненської та Волинської областей. ПрАТ «Тернопільський молокозавод» представить свою нову продукцію у торгових мережах у яких уже $\epsilon$ продукція підприємства. У місті Тернопіль - це супермаркети: «Novus», «Прогрес», «Фора», «Барвінок», «Наш край», «Берегиня» та магазини біля дому із 
якими заключені договори про постачання. У місті Рівне - це супермаркети: «Вопак», «Фора», «Екомаркет», «Колібріс», «Метро» та магазини біля дому із якими заключені договори про постачання. У місті Луцьк - це супермаркети: «Пако», «Наш Край», «Колібріс», «Гурман», «Там Там» та магазини біля дому із якими заключні договори про постачання.

Для інформування потенційних споживачів про нову продукцію ТМ «Молокія Казкова», а саме дитячий йогурт пропонується використовувати: рекламу, стимулювання збуту та PR.

Товарна стратегія нового товару. У процесі формування товарного асортименту слід дотримуватися стратегічного підходу. До основних стратегій товарного асортименту можна віднести: поглиблення асортименту, підтримка марок, скорочення асортименту, звуження асортименту (рис. 4).

\begin{tabular}{|c|c|c|}
\hline & Додавання до асортименту & $\begin{array}{c}\text { Виключення } \\
\text { 3 асортименту }\end{array}$ \\
\hline $\begin{array}{c}\text { Глибина } \\
\text { асортименту }\end{array}$ & Поглиблення асортименту & Скорочення асортименту \\
\hline $\begin{array}{c}\text { Широта } \\
\text { асортименту }\end{array}$ & Розширення асортименту & Звуження асортименту \\
\hline
\end{tabular}

Рис. 4 Стратегія товарного асортименту ТМ «Молокія Казкова»

Для товарного асортименту ТМ «Молокія Казкова» згідно результатів дослідження доцільно обрати стратегію «розширення асортименту». Дана стратегія реалізується шляхом додавання товарних груп, тобто виведенню на ринок нового товару (дитячий йогурт $2,7 \%$ жирності).

5. Ринкова стратегія нового товару включає в себестратегію охоплення ринку, конкурентну стратегію та стратегію позиціонування. Стратегія охоплення ринку передбачає сегментацію ринку, що включає в себе макро- та мікросегментацію (табл. 3). 
Макросегментація ринку для дитячого йогурту ТМ «Молокія Казкова» дитячого йогурту $2,7 \%$ жирності

\begin{tabular}{|l|l|l|}
\hline \multicolumn{1}{|c|}{ ЩО? } & \multicolumn{1}{|c|}{ КОМУ? } & \multicolumn{1}{c|}{ ЯК? } \\
\hline Угамування голоду & & Дитячий йогурт 2,7\% \\
Угамування спраги & Споживчий & жирності зі смаками: без \\
Насичення організму біфідобактеріями & ринок & наповнювача; ; яблуко- \\
$\begin{array}{l}\text { Насичення організму білками } \\
\text { Насичення організму лактозою та пробіотиками } \\
\text { Підтримка імунітету }\end{array}$ & & груша та чорниця-малина \\
\hline
\end{tabular}

Для визначення потенційних споживачів нової продукції ТМ «Молокія Казкова» було проведено мікросегментацію (табл. 4).

Таблиия 4

Мікросегментація ринку для дитячого йогурту ТМ «Молокія Казкова» дитячого йогурту $2,7 \%$ жирності

\begin{tabular}{|c|c|}
\hline \begin{tabular}{|l} 
Географічні критерії \\
\end{tabular} & Демографічні критерії \\
\hline $\begin{array}{l}\text { • Тип місцевості: } \\
\text { - } \quad \text { В2В: Тернопільська, Волинська та Рівненська } \\
\text { області. } \\
\text { - } \quad \text { В2С: Тернопільська, Волинська та Рівненська } \\
\text { області. }\end{array}$ & $\begin{array}{l}\text { - } \quad \text { Стать: Жіноча, чоловіча; } \\
\text { - } \quad \text { Вік:від18 до 70; } \\
\text { - } \quad \text { Розмір сім’ї: від } 2 \text { до } 6 \text { осіб в сім’і; } \\
\text { - } \quad \text { Рівень доходу :середній; вище } \\
\text { середнього; } \\
\text { - Освіта: середня; вища; } \\
\text { - Національність: не має значення. } \\
\text { - } \quad \text { Віросповідання: не має значення. }\end{array}$ \\
\hline Поведінкові критерії: & Психографічні критерії: \\
\hline $\begin{array}{l}\text { - Первинні переваги: безпека та якість продукції; } \\
\text { корисність для здоров’я. } \\
\text { • Привід для здійснення покупки: угамування } \\
\text { голоду; підтримка здоров’я (насичити організм } \\
\text { біфідобактеріями, білками, лактобактеріями, } \\
\text { лактозою та пробіотиками, кальцій); стимулювання і } \\
\text { активізація травлення) } \\
\text { • Статус користувача( регулярний та починаючий } \\
\text { споживач); } \\
\text { • Інтенсивність споживання (часто: майже кожного } \\
\text { дня); } \\
\text { - Ступінь прихильності: висока; } \\
\text { - Ступінь готовності до сприйняття товару: націлений } \\
\text { купити. }\end{array}$ & $\begin{array}{l}\text { • Образ життя: традиціоналісти, } \\
\text { життєлюби; } \\
\text { • Тип особистості: конформісти; } \\
\text { помірковані }\end{array}$ \\
\hline
\end{tabular}

Зробивши мікросегментацію для ТМ «Молокія Казкова» дитячий йогурт було запропоновано наступні сегменти:

Сегмент 1. Молоді, активні люди, що мають своїх дітей, слідкують за новинками. Вони слідкують за здоров'ям своїх дітей та ретельно обирають молочну продукцію для дітей, віком від 19-35 років:жінки у декретній відпустці, офісні працівники та студенти старших курсів та рівнем доходу середній (від 5 тис. грн./міс.). 
Сегмент 2: Люди віком від 32 до 55 років, що мають дітей та піклуються про їх здоров'я, ретельно обирають продукцію читаючи тематичні статті та перевірки експертів молочної продукції, рівень доходу середній, вище середнього (від 6 тис. грн./міс.).

Сегмент 3. Зрілі, досвідчені люди, зі сформованими життєвими цінностями, віком від 50-72 років, що мають власних дітей та онуків. Купують молочну продукцію для дітей та онуків, ретельно обирають продукцію прислуховуючись до експертів та лідерів думок, дохід: нижче середнього, середній та вище середнього.

Потенційними споживачами дитячого йогурту ТМ «МолокіяКазкова» $\mathrm{\epsilon}$ молоді матусі, які купують молочну продукцію для своїх дітей. Також це можуть бути молоді татусі, хресні батьки чи бабусі малюків для яких розробляється дитячий йогурт. Споживчою цінністю продукції ТМ «МолокіяКазкова» $\epsilon$ яскравий логотип продукції, що одразу асоціюється з дитинством.

Основними конкурентами торгових марок для дитячого йогурту ТМ «Молокія Казкова» являються ТМ «Тема», ТМ «Агуша», ТМ «Яготинське для дітей» та торгова марка «Злагода». Вони ж і являються найнебезпечнішими конкурентами, так як забезпечують найбільший відсоток продажів на ринку, а їх продукція конкуруватиме 3 дитячим йогуртом торгової марки «Молокія Казкова» в разі виведення нового товару на ринок, так як характерна подібними споживчими властивостями.

Фактори конкурентоспроможності для порівняльного аналізу: технологія виробництва, ціна на продукцію; натуральність сировини, упаковка, термін зберігання, смакова лінійка продукції.

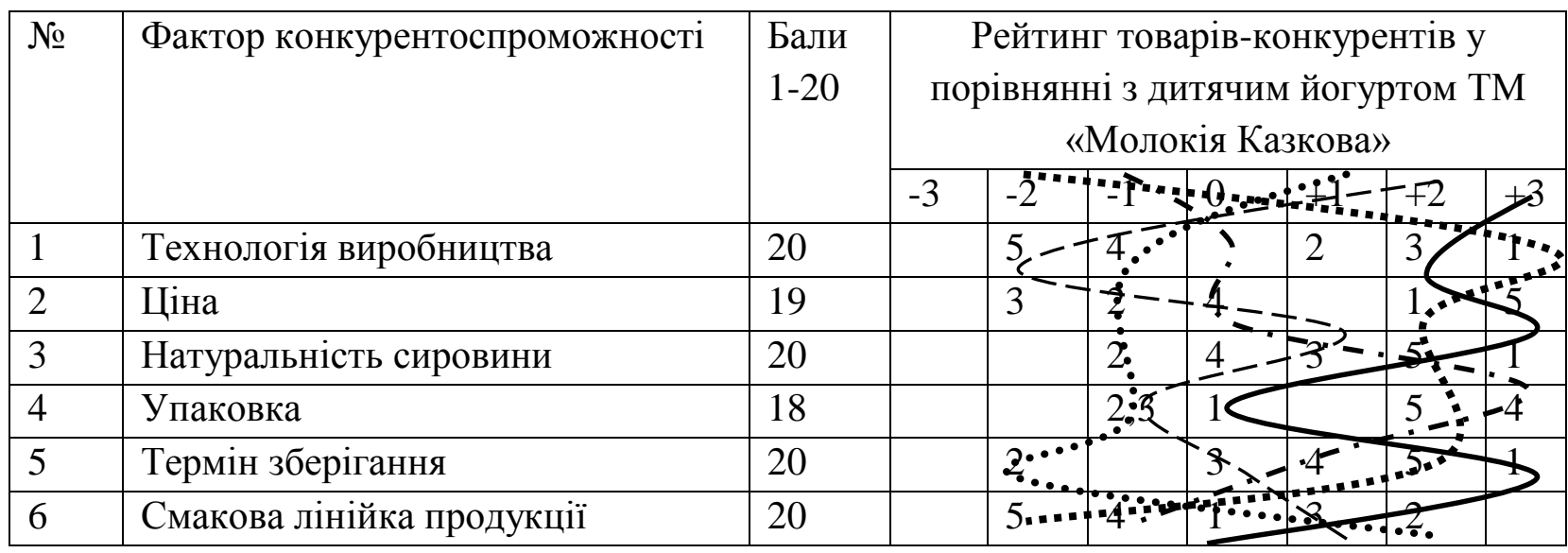

Рис. 6. Конкурентні переваги дитячого йогурту «Молокія Казкова»

* 1: ТМ «Молокія Казкова», 2: ТМ: «Тема», 3: «Агуша», 4: «Яготинське для дітей», 5: «Злагода».

3 порівняльного аналізу можна зробити висновок, що дитячий йогурт ТМ «Молокія Казкова» переважає за рахунок технології виробництва, натуральність сировини та терміну зберігання продукції. Тобто для нової продукції ТМ «Молокія Казкова» доцільно обрати стратегію конкурентної поведінки: стратегію виклику лідера. Так, як на ринку вже існують торгові марки, що випускають дитячу молочну продукцію, але ТМ «Молокія Казкова» займає лідируючі позиції 
серед інших торгових марок у областях, де планується випуск нової продукції, тому доцільно обрати саме цю стратегію.

Стратегія позиціонування розробляється для трьох сегментів, які були розглянуті вище. Параметри, що впливають на споживчу цінність при формуванні стратегії позиціонування: зберігання поживних речовин в технологічному процесі; екологічність упаковки; смакові якості; натуральність продукції; збалансування (складу); термін зберігання продукції.

Для вибору позиції було проаналізовано багатовекторні карти позиціонування. Перша карта позиціонування - це об'єктивна карта, що відображає співвідношення марок за об'єктивними показниками,тобто на основі результатів дослідження.

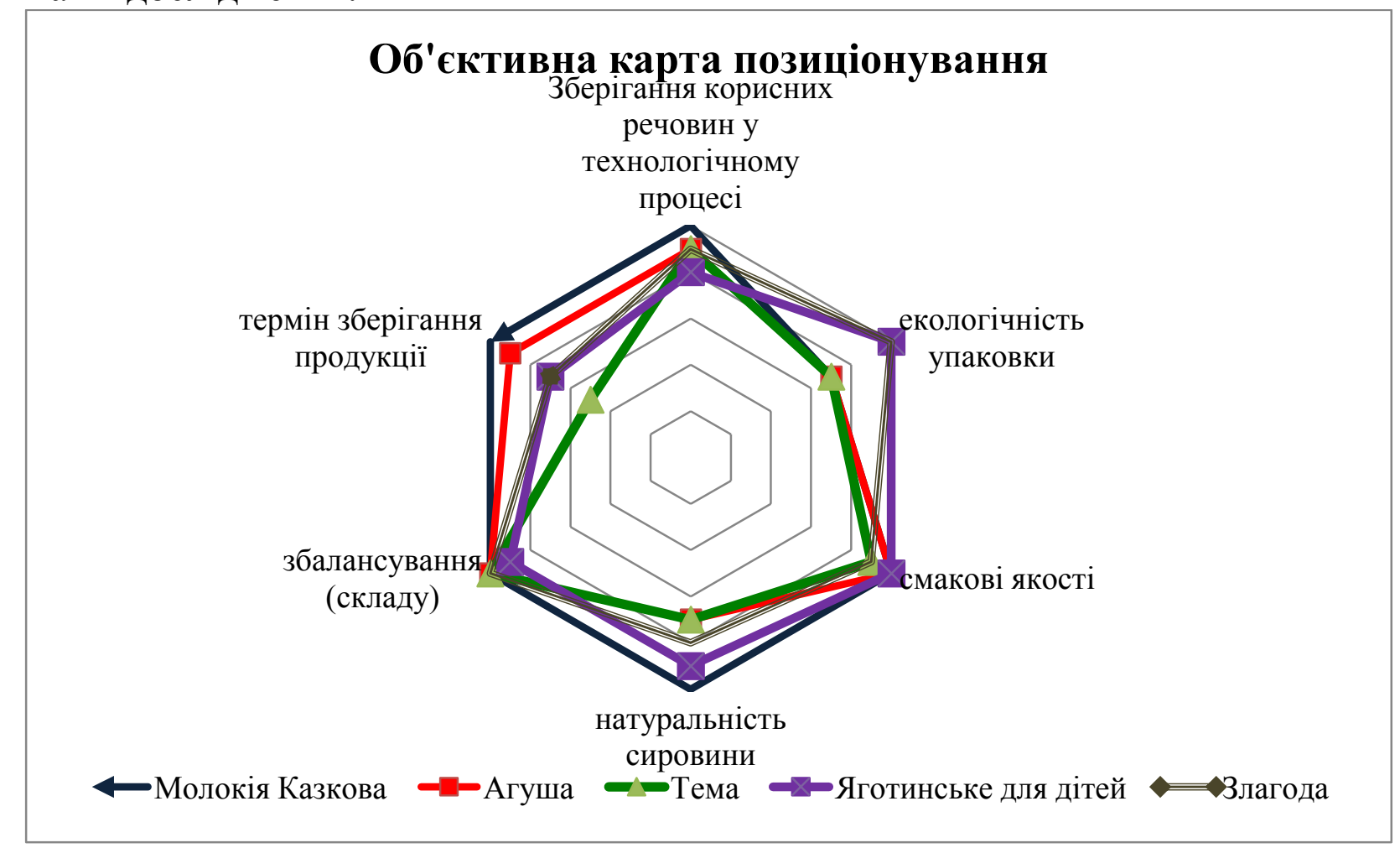

Рис. 7. Багатовекторна об'єктивна схема позиціонування ТМ «Молокія Казкова» дитячий йогурт $2,7 \%$ жирності

Аналіз багатовекторної об’єктивної карти позиціонування показав, що найбільшу силу за параметром зберігання корисних речовин у технологічному процесі, натуральність сировини, збалансування (складу) та термін зберігання продукції має йогурт дитячий ТМ «Молокія Казкова». За параметром смакові якості та збалансування (складу) найкращі показники має дитячий йогурт ТМ «Агуша». Торгова марка «Тема» має найкращий показник у критерії збалансування (складу) дитячого йогурту. Найгіршим показником дитячого йогурту ТМ «Молокія Казкова» $є$ екологічність упаковки, так, як продукція реалізується тільки у пляшках та контейнерах HDPE. 
Виходячи 3 проведеного аналізу обираємо тип позиціонування: позиціонування що основане на відмінній якості товару. Тому, що в тих регіонах де представлена продукція ТМ «Молокія», вона $\epsilon$ серед лідерів виробників молочної продукції. Та також дійсно має відмінну якість своєї продукції, що підтверджена використанням європейськох технології під час виробництва молочних продуктів, та відповідність європейським стандартам продукції ТМ «Молокія Казкова».

Висновки. В умовах економічної кризи попит на ринку молочних продуктівз кожним роком зменшується, в результаті чого конкуренція на ринку зростає. Таким чином, підприємствам необхідно орієнтуватися на задоволення потреб споживачів, впроваджуючи на ринок нові товари.За результатами висновків, одержаних у теоретико-методологічному аспекті та даних, отриманих у результаті маркетингового дослідження запропоновано удосконалення асортиментної політики.

Наукова новизна полягає в розроблені моделі виведення на ринок нового товару, яка складається 3 шести етапів: аналіз мікро- та макросередовища підприємства, методи формування товарного асортименту, концепція нового товару, виведення нового товару, товарна стратегія, ринкова стратегія нового товару. Дана модель може бути використана для ПрАТ «Тернопільського молокозаводу» для подальшого формування асортиментної політики. Запропоновано процес виведення нового товару ТМ «Молокія Казкова», а саме дитячого йогурту для дітей від 8 місяців. Надані рекомендації щодо сегментування, позиціонування та комплексу маркетингу для нового товару.

\section{Література:}

1. Гриньов В. Ф. Товарно-инновационная политика предприятия : [учебное пособие] / Гриньов В. Ф.- К. : МАУП, 2004. - 160 с.

2. Кардаш В. Я. Товарнаінноваційнаполітика : [підручник] / В. Я. .Кардаш, І. А. Павленко, О. К.

3. Кубишина Н.С. Впливжиттевого циклу товару на конкурентоспроможністьпідприємств / Н. С. Кубишина // Економічнийвісник НТУУ „КПІ”. - 2007. - № 4 C. $252-257$.

4. Кубишина Н.С. Основні напрямки розробкитоварноїполітики / Н.С. Кубишина // Економіка: проблемитеорії та практики. Збірникнауковихпраць. - 2001. - №6. - С. 43-52.

5. Ленсколд Д. Визначення ефективності маркетингової діяльності на прикладі молокопереробного підприємства ПрАТ «Тернопільський молокозавод» //Рецензенти. - С. 207.

6. Нікітін І. В. Поняття, види продуктових інновацій та методи оцінки ефективності ї запровадження підприємством / І. В. Ні-кітін // Соціально-економічні явища та процеси. - 2011. - № 12. - C. 217-221.

7. Чухрай Н. Інновації і логістикатоварів : [монографія] / Н. Чухрай, Р. Патора. - Львів : Вид-воНУ “Львівськаполітехніка”, 2001. - 264 с.

8. Чухрай Н.I Маркетинг інновацій: підручник/Н.I.Чухрай. - Львів: Видавництво Львівської політехніки, 2011. - 256 с.

9. Robertson T. Innovation, Behavior and Communication / T. Robertson. - Holt, Rinehart and Wiston, 1971. 
10. Офіційний сайт ПрАТ «Тернопільський молокозавод [Електронний ресурс] : Режим доступу:http://molokija.com/ua. - Назва з екрана. 